\title{
Should Discectomy Performed Without Replacement be the First Choice in Patients with Pain and Reduced Mouth Opening?
}

\author{
Yerine Bir Şey Konulmaksızın Yapılan Diskektomi Ameliyatı Ağrı \\ ve Limitli Ağız Açıklığı Olan Hastalarda IIlk Tercih Olmalı mıdır? \\ (D) Burcu Gürsoytrak, (1) Umut Demetoğlu
}

Aydın Adnan Menderes University Faculty of Dentistry, Department of Oral and Maxillofacial Surgery, Aydın, Turkey

Keywords

Temporomandibular joint, discectomy, internal derangement, Wilkes stage

Anahtar Kelimeler

Temporomandibular eklem, diskektomi, iç düzensizlik, Wilkes evreleri

Received/Geliş Tarihi : 28.05 .2020

Accepted/Kabul Tarihi : 08.07.2020

doi:10.4274/meandros.galenos.2020.40327

Address for Correspondence/Yazışma Adresi: Burcu Gürsoytrak DDS, MD,

Aydın Adnan Menderes University Faculty of Dentistry, Department of Oral and Maxillofacial Surgery, Aydın, Turkey

Phone : +90 25621339 39-44 08

E-mail :dt_burcupoyraz@hotmail.com

ORCID ID: orcid.org/0000-0002-9893-0649

(C) Meandros Medical and Dental Journal, Published by Galenos Publishing House.

This is article distributed under the terms of the Creative Commons Attribution NonCommercial 4.0 International Licence (CC BY-NC 4.0).

\begin{abstract}
Objective: In this study, we evaluated the pain and functional development of patients with internal derangements before and after discectomy.

Materials and Methods: This was a retrospective cohort study in which patients with internal derangement underwent discectomy without replacement. The main primary variables were pre- and post-operative maximum mouth opening (MMO) and pain according to the Visual Analogue scale (VAS). Paired t-test was used to compare means to determine the differences between pre- and post-operative mouth opening and pre- and post-operative VAS.

Results: Among the 20 patients included in this study, six and 14 underwent bilateral and unilateral discectomy without replacement, respectively. Paired sample t-test results revealed that there was a difference in MMO pre- and postoperatively, whereas the VAS scale showed no difference in terms of pain. According to the Wilkes classification, the difference between pre- and post-operative MMO of the patients was recorded. Based on these findings, no difference was observed between the mean pre- and post-operative MMOs of Wilkes stage III and IV patients, whereas a significant difference was found between Wilkes stage $V$ and III patients $(p<0.05)$. No significant difference was found between Wilkes stage IV and $\mathrm{V}$ patients $(\mathrm{p}>0.05)$.

Conclusion: In Wilkes stage III and IV subjects, discectomy without replacement is a good treatment option to relieve pain and improve functions in cases where conservative treatment fails.
\end{abstract}

Öz

Amaç: Bu çalışmada; diskektomi operasyonu öncesi ve sonrası iç düzensizlikleri olan hastaların, ağrı ve fonksiyonel gelişimi değerlendirildi.

Gereç ve Yöntemler: Bu retrospektif kohort çalışmada internal düzensizliği olan hastalara yerine bir şey konulmaksızın diskektomi uygulanan hastaların ağrı ve fonksiyonel gelişimi değerlendirildi. Birincil ana değişkenler ameliyat öncesi ve sonrası maksimum ağız açıklığı (MAA), Görsel Analog skalasına (VAS) göre ağrı idi. 
Ortalamaları, farkıııkları, ameliyat öncesi ve sonrası ağız açıkığı ile ameliyat öncesi ve sonrası VAS'si belirlemek için eşleştirilmiş̧ örnekelem t-testi kullanıldı.

Bulgular: Altısı bilateral ve 14'ü unilateral olmak üzere yerine bir şey konulmaksızın diskektomi uygulanan toplam 20 hasta çalısmaya dahil edildi. Eşleştirilmiş örneklem t-testi sonuçları; ameliyat öncesi ve sonrası MAA'da bir fark olduğunu, VAS ölçeğinde ise ağrı açısından fark olmadığını göstermiştir. Wilkes sınıflandırmasına göre hastaların ameliyat öncesi ve sonrası MAA değerleri arasındaki fark hastaların dosya verilerinden kaydedilmiştir. Bu bulgulara dayanarak, evre III ve IV'teki hastaların ameliyat öncesi ve sonrası ortalama MAA'ları arasında fark gözlenmezken, evre V ve III'teki hastalar arasında anlamlı bir fark görülürken $(p<0,05)$; Wilkes evre IV ve $V$ arasında anlamlı fark bulunmamıştır $(p>0,05)$.

Sonuç: Wilkes III ve IV hastalarında yerine bir şey konulmaksızın diskektomi, konservatif tedavinin başarısız olduğu durumlarda ağrıyı hafifletmek ve fonksiyonları iyileştirmek için iyi bir tedavi seçeneğidir.

\section{Introduction}

Internal derangement of temporomandibular joint (TMJ) refers to the abnormal relationship between the articular disc and mandibular condyle, fossa, and articular tubercle (1). Internal derangements of TMJ are traumatic-origin and progressive organic lesions. Since progressive degenerative conditions may occur, its effective clinical evaluation has become important (2). Internal derangements of TMJ have a significant place among the joint disorders and are the most difficult cases treated by maxillofacial surgeons (3). These derangements are in close relationship with the displacement of the disc. Symptoms are usually pain in muscles, preauricular or TMJ region. Besides the pain, TMJ sounds called crackling or crepitus are often heard in patients with TMJ as well as limitation and deviation during mandibular movements $(4,5)$. Some patients experience a reduced joint dysfunction following a short joint crackling and popping history and although symptoms of displaced disc or osteoarthritic changes and similar clinical symptoms are seen in most of these patients, they can continue their daily life activities without any limitation (6). Asymptomatic patients are prone to have unilateral distress in the joint and are at a lower stage of Wilkes classification compared to symptomatic patients, but in both cases, symptomless joint disc displacement is possible to occur (7). Patients usually have such symptoms as pain, dysfunction, having difficulties while opening their mouths and exhaustion. Making the differential diagnosis of TMJ disorders and defining the disease correctly are very important for the treatment. Symptoms of the disease can be easily confused with relatively simple muscle spasms. Anamnesis, a detailed clinical examination and advanced imaging techniques should be used in the diagnosis of these disorders and the data should be carefully evaluated.

Numerous methods have been followed in the classification of internal TMJ derangements. There are many classifications that many researchers have created by their own methods. Although there are many classifications by researchers such as Helkimo and the classifications used with the modifications made on them, the most commonly used classification is the Wilkes classification. Wilkes classified this disorder according to the degenerative changes described during surgery (2).

For the last 40 years, various techniques have been used for joint surgery. These include repositioning of the disc, eminectomy, high condylectomy, discopexy, discectomy, modified condylectomy, arthroscopic lysis and lavage. Studies with long-term follow-up duration have reported several complications and high success rates for the patients who underwent discectomy alone without replacement $(8,9)$. Of these, discectomy is the most widely used procedure for joint pain (10), which has the best long-term data results $(11,12)$. Other signs include different underlying pathologies, their relation, the ability of the surgeon to interpret these symptoms because the symptoms of internal derangement of the joint are often confusing, and the selection of surgical technique $(13,14)$.

This study aimed to evaluate the pre- and postoperative pain and the efficacy of discectomy used to improve the mandibular function in patients with internal derangement as well as evaluating the success of discectomy in patients at different stages of the Wilkes classification.

\section{Materials and Methods}

The study included patients who underwent discectomy without replacement to TMJ between 
2013 and 2018 at Aydın Adnan Menderes University Faculty of Dentistry (Aydın, Turkey). This retrospective cohort study was performed by two surgeons with similar experience and ethics committee approval was obtained and was conducted in accordance with the guidelines of the World Medical Association Declaration of Helsinki and the Local Ethics Committee of Adnan Menderes University (Aydın, Turkey) approved it with 2018/049 ethical number. An informed consent was obtained from all patients.

The inclusion criteria were as follows: 1) Patients above 18 years of age with painful mandibular movement and with a maximal mouth opening (MMO) of less than $35 \mathrm{~mm}$. 2) Patients whose clinical examination was performed at least once, those who underwent magnetic resonance imaging (MRI) before the surgery, those who were diagnosed with internal derangement and classified according to the Wilkes classification. 3) Patients who had previously been diagnosed with internal derangement and did not respond to non-surgical medical treatments applied including hot application, soft diet, acupuncture, transcutaneous electrical nerve stimulation, massage, physiotherapy, occlusal splint, and arthrocentesis. Only subject 8,9,10,11 and 19 who had normal MMO but discectomy had been done from violent pain.

Surgical indication was decided considering the clinical diagnosis, findings and symptoms. For all patients, modified endaural approach, described by Al-Kayat and Bramley, was used for discectomy (Figure 1). When the lateral joint surface was reached, local anaesthesia was performed for haemorrhage in the upper joint cavity and the horizontal incision was applied and the disc was isolated from all surfaces and removed through blunt dissection. The mandibular MMO was manipulated and joint surfaces were observed to ensure an easy condylar rotation and translation. Then, hyaluronic acid was injected into the region to provide lubrication in the mandibular movement and the wound was closed with all layers. All patients were given $1 \mathrm{gr}$ cefazolin and $8 \mathrm{mg}$ dexamethasone intravenously.

\section{Study Variables}

The primary main variables were pre and post-operative MMO, pain according to the visual analogue scale (VAS). A standard compass was used to measure the MMO from the incisal angles of the maxillary and mandibular incisors. In addition to these main variables, pain in the pre and post-operative movements according to the VAS, clicking, muscle pain and TMJ pain in palpation were also evaluated. All patients were graded according to the Wilkes classification before the operation, and the degree of relief was recorded after these operations.

\section{Statistical Analysis}

Paired t-test was used to determine means, differences, pre and post-operative mouth opening, and pre and post-operative VAS. Statistical analysis was performed using SPSS software and a $p$ value of $<0.05$ was considered statistically significant.

Tukey test was used to identify the variables in the groups to evaluate whether they caused the differences. The significance levels were assessed by a difference of less than $0.05(p<0.05)$.

\section{Results}

There were 20 patients with complete files in this retrospective study. Of these patients, six and fourteen underwent bilateral and unilateral discectomy without replacement, respectively. Stages were determined according to Wilkes classification; six were at stage III, nine were at stage IV, and five were at stage $\mathrm{V}$. These patients had many subjective

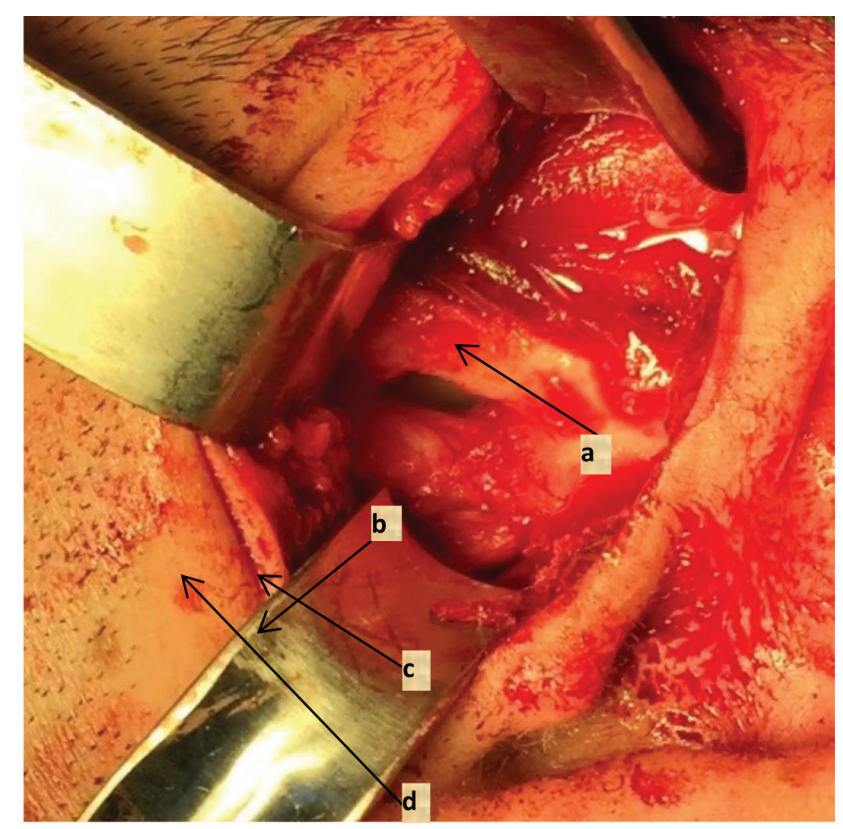

Figure 1. Intraoperative view of modified endaural approach and discectomy

a) temporalis superficialis facia b) disc c) fossa mandibularis d) eminence 


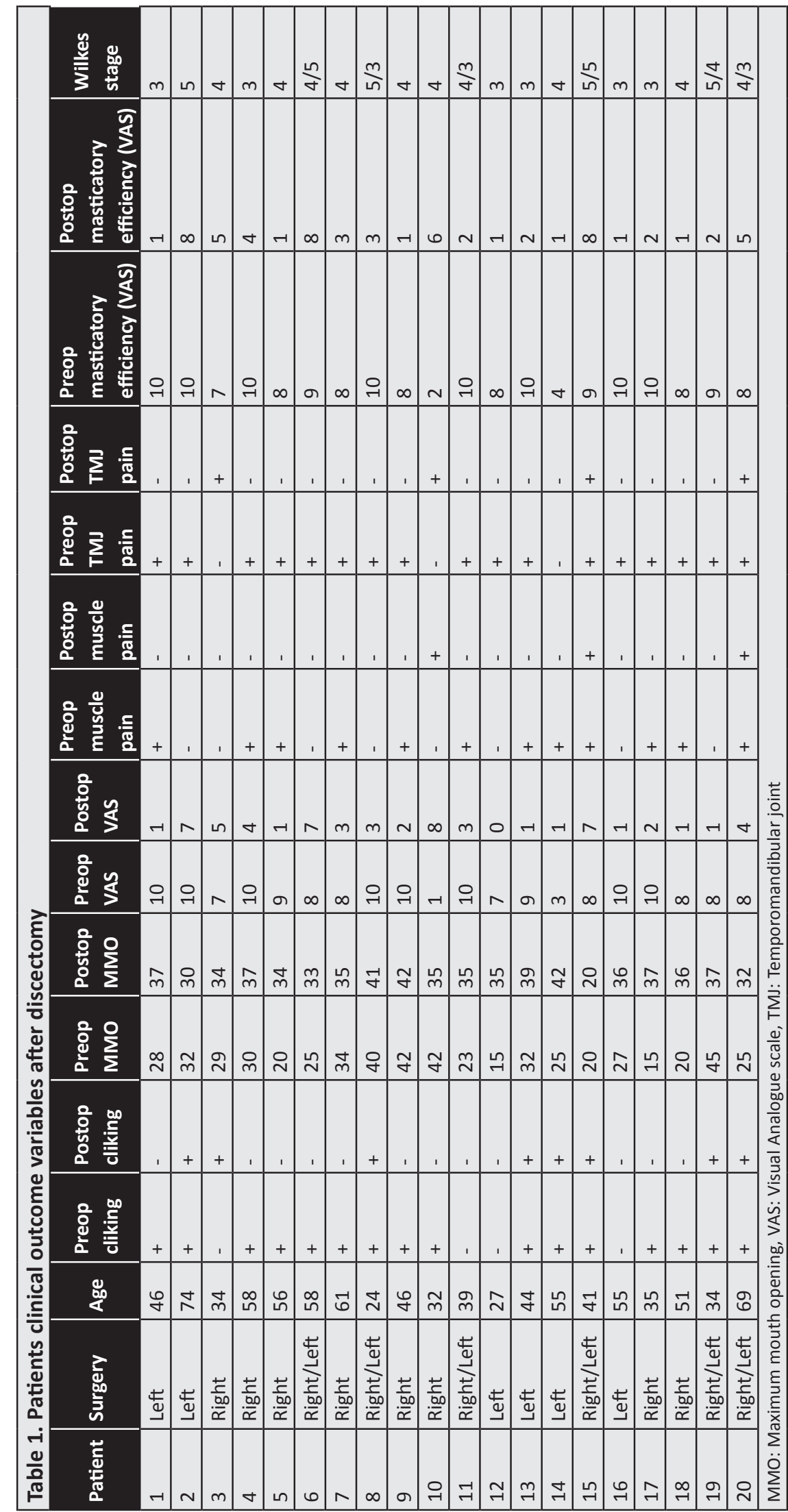

symptoms, including joint pain, pain in chewing muscles and stiffness in the neck, clicking, pain in the mandibular movement, pain in palpation in the chewing muscles, opened or closed locks, limitation in chewing, and headache (Table 1).

The MMO and VAS scale in the patients' files were examined. Paired sample t-test results revealed that there was a difference in MMO before and after surgery, while VAS scale showed no difference in terms of pain (Table 2).

According to the Wilkes classification, the difference between pre and post-operative MMO of the patients was recorded. Tukey's test was used to determine whether the difference was significant according to the Wilkes classification. Mean pre and postoperative MMOs of the patients, who were at Wilkes stage III, were $24 \mathrm{~mm}$ and $36.71 \mathrm{~mm}$, respectively. Mean pre and post-operative MMOs of the patients, who were at Wilkes stage IV, were $29.12 \mathrm{~mm}$ and $35.75 \mathrm{~mm}$, respectively. Mean pre and post-operative MMOs of the patients, who were at Wilkes stage $V$, were $32.4 \mathrm{~mm}$ and 33.2 $\mathrm{mm}$, respectively. Based on these findings, no difference was observed between the mean pre and postoperative MMOs of patients at stage III and IV, while a significant difference was found between the patients at stage $\mathrm{V}$ and III $(\mathrm{p}<0.05)$. No significant difference was found between Wilkes stage IV and V ( $p>0.05$ ) (Table 3).

Three patients at Wilkesstage $\mathrm{V}$ andonepatient at Wilkesstage IV underwent modified condylectomy. The total number of condylectomies was four. Improvement was observed in terms of painand $\mathrm{MMO}$ 
in all of these patients who underwent a second surgery. Subject 2,6,15 classified Wilkes stage V and subject 10 classified Wilkes stage IV had an increase in the VAS from preoperative score a postoperative score (Table 1 ). This subjects also had a decrease in mouth opening. This subject 2,6,10,15 required further treatment and was the treatment condylectomy. Sixteen of 20 patients did not require a second surgical procedure.

\section{Discussion}

In this retrospective study, patients with different rates of joint degeneration according to the Wilkes classification was treated with discectomy without replacement. There are studies in which a large number of displaced and deformed discs are reshaped and repositioned. There are also studies in which the degenerated disc is removed and replaced with temporary or permanent different disc materials. In another perspective, extracapsular approach as well as eminectomy and modified condylectomy without removing the risk are also preferred. There is no golden standard in the literature for any surgical technique with a potential of low morbidity and high success. Although many long-term studies have proven that discectomy without replacement provides successful results (15-17). In a study by Dimitroulis
(18), discectomy performed with dermal graft has been reported to cause less crepitation sound during joint function, compared to discectomy. In a study by Holmund et al. (19), 24 chronic closed locks patients and 27 patients with reciprocal clicking underwent discectomy without replacement. As a result of the six-month follow-up of the patients, it was found that their MMO were $35 \mathrm{~mm}$ and above, functional development was at least $40 \%$, and scoring downed below four in the VAS scale. In our study, among the patients, who underwent discectomy without replacement, MMO of those who were at Wilkes stage III increased by an average of $12.71 \mathrm{~mm}$, while MMO of the patients at Wilkes stage IV and V increased by $6.63 \mathrm{~mm}$ and $0.8 \mathrm{~mm}$ on average, respectively. Among these patients, the status of those who were at Wilkes stage III and IV were found to be improved in terms of clicking, locking, pain in the palpation of muscles, and pain in mandibular movement. However, those who were at Wilkes stage $V$ (subject $2,6,15$ ) and IV (subject 10) underwent a high condylectomy due to the fact that their pains were not relieved. Following this, improvement was observed in terms of pain and $\mathrm{MMO}$ in four of these patients who underwent a second surgery. All of thesepatients (subject $2,6,10,15)$ who underwent a high condylectomy were relieved post-operatively.

\begin{tabular}{|l|l|l|l|}
\hline Table 2. Comparision of meanchanges in the clinic outcome variables & Correlation & Sig. & 0.800 \\
\hline Preop cliking \& postop cliking & N & -0.052 & 0.279 \\
\hline Preop muscle pain \& postop muscle pain & 26 & 0.220 & 0.060 \\
\hline Preop TMJ pain \& postop TMJ pain & 26 & -0.374 & $0.005^{*}$ \\
\hline Preop MMO \& postop MMO & 26 & 0.534 & 0.233 \\
\hline Preop VAS \& postop VAS & 26 & -0.243 & -0.068 \\
\hline Preop masticatory efficiency \& postop masticatory efficiency (VAS) & 26 & 26 & -0.741 \\
\hline MMO: Maximum mouth opening, VAS: Visual Analogue scale, TMJ: Temporomandibular joint, *Paired sample t-test \\
\hline
\end{tabular}

\begin{tabular}{|c|c|c|c|c|c|c|}
\hline & & Mean difference & Standard error & Significant & Lower bound & Upper bound \\
\hline \multirow{2}{*}{ Wilkes 3} & Wilkes 4 & 4.83838 & 2.80937 & 0.219 & -2.1972 & 11.8740 \\
\hline & Wilkes 5 & 9.61111 & 3.29428 & $0.020 *$ & 1.3611 & 17.8611 \\
\hline \multirow{2}{*}{ Wilkes 4} & Wilkes 3 & -4.8383 & 2.80937 & 0.219 & -11.8740 & 2.1972 \\
\hline & Wilkes 5 & 4.77273 & 3.17223 & 0.307 & -3.1716 & 12.7171 \\
\hline
\end{tabular}


Six of the patients had bilateral discectomy, while 14 patients underwent unilateral discectomy. Among those patients who had bilateral discectomy, three of the patients, whose at least one side was at Wilkes stage $V$, underwent a second surgery (subject 2,6,15). And those patients who had unilateral discectomy, one of the patients, whose only one side was at Wilkes stage IV, underwent a second surgery (subject 10) .We attributed this to the fact that patients who underwent bilateral discectomy with at least one side at Wilkes stage $V$ had less improvement after discectomy, compared to other patients (those who were at Wilkes stage III and IV and who underwent unilateral discectomy).

As stated by Miloro et al. (17), if the jaw is responsible for the reduction of jaw functions and if the anatomical problem cannot be solved by nonsurgical and minimally invasive procedures, the disc must be removed without being inserted again. If the morphology of the disc is abnormal and it provides a poor TMJ disc-condyle-fossa relationship, mandibular movement will be restricted in which the disc must also be removed (17). In particular, minimal invasive surgeries such as arthrocentesis and arthroscopy can be tried to treat abnormalities in the disc position or morphology of Wilkes stage I to III. However, as stated by Zhang et al. (20), minimal invasive surgeries do not provide a permanent solution for Wilkes stages IV and $\mathrm{V}$ due to the potential risk of relapse. Furthermore, a temporary vascular tissue formation can be induced in the region by using a dermis-fat graft of the disc, temporal muscle flap or fat tissue following the discectomy. However, jaw movements can be restricted since fat is too soft and easily shredded and it creates potential tissue for scar. Dermis-fat graft is used to fill the joint space after discectomy (21). Dermis-fat grafts are a physical barrier for heterotypical bone formation and fibrosis $(22,23)$, but do not always protect the condyle from degenerative changes like osteoarthritis (22). In a study by Dimitroulis (22), joint replacement and condylectomy were required due to the development of osteoarthritis in eight of 123 patients. In the studies by Hansson et al. (24) and Takaku et al. (25), MRI findings of the patients, who underwent discectomy without replacement, have revealed that the intervening soft tissue having direct contact with the thick articular surfaces has filled the joint space. Therefore, the advantages of filling of the joint space by abdominal dermis-fat graft or fat graft after discectomy in these patients may not neutralize the disadvantages of creating a second surgical site, post-operative pain, and morbidity. In this case, if there is a possibility of a degenerative change in the condyle in the cases whose joint space is filled, should discectomy performed without replacementbe the first choice in patients in terms of pain and morbidity?

Nyberg et al. (16) included only the patients with unilateral internal derangement for whom they applied discectomy without replacement. In a study by Miloro et al. (17), 23 patients who underwent discectomy without replacement (11 were unilateral; 6 were bilateral) were included. In our study, bilateral discectomy and unilateral discectomy were applied for six and 14 patients, respectively. A limitation of our study may be the combined evaluation of patients who underwent unilateral and bilateral discectomy. We believe that patients who have operated for the second time may have changed the result since the first surgeries were considered in the pre and postoperative evaluation of pain in the VAS. Because in our clinical evaluations, post-operative records of patients who had unilateral discectomy were positive.

Success criteria for TMJ meniscectomy, recommended by second Goss (26) and Holmlund et al. (8) are as follows:

i. Mild, short and sparse pain without any concern

ii. Vertical mandibular movement of more than $35 \mathrm{~mm}$; protrusive and lateral mandibular movement of more than $6 \mathrm{~mm}$

iii. Being able to consume the routine diet easily by avoiding hard foods at worst

iv. Stability of changes in possible degenerative images in imaging

v. Absence of significant complications

vi. Absence of symptoms for at least two years

In a study by Hansson et al. (24), MMO of all patients was increased during the one-year follow-up period, and no pain was reported in 20 of 28 patients, however, four patients reported residual pain one year later. Takaku et al. (25) reported no restricted mouth opening in 31 of 35 patients followed by long-term MRI, who underwent discectomy without replacement. Additionally, 32 of the patients reported no pain while three had pain only in occlusal movements. Based on i,ii,iii and v no success criteria, 
we believe that we have achieved $80 \%$ success in 16 of 20 patients without requiring any second surgery. No patients at the Wilkes stage III was required to be reoperated; our success rate was $100 \%$. However, four of our patients with Wilkes stage $V$ on one side and Wilkes stage $\mathrm{V}$ or IV on the other were required to be operated for the second time. This meant $20 \%$ success. However, after performing modified condylectomy in these patients, our success rate increased to $100 \%$. We believe that the use of discectomy in cases where conservative treatment fails is significant. However, we would like to state that case-adapted treatment is significant for the patients at Wilkes stage V.

\section{Conclusion}

We believe that discectomy surgery without replacement is a good treatment option to relief the pain and improve the functions in cases where conservative treatment fails. Future studies with a larger patient population evaluating the relationship between the condyle and fossa in details for longer period of time will provide a better understanding of the results.

\section{Ethics}

Ethics Committee Approval: This retrospective cohort study was performed by two surgeons with similar experience and ethics committee approval was obtained and was conducted in accordance with the guidelines of the World Medical Association Declaration of Helsinki and the Local Ethics Committee of Adnan Menderes University (Aydın, Turkey) approved it with 2018/049 ethical number.

Informed Consent: Informed consent was obtained from all patients.

Peer-review: Externally peer-reviewed.

\section{Authorship Contributions}

Concept: B.G., Design: B.G., Data Collection or Processing: B.G., U.D., Analysis or Interpretation: B.G., U.D., Literature Search: B.G., Writing: B.G.

Conflict of Interest: No conflict of interest was declared by the authors.

Financial Disclosure: The authors declared that this study received no financial support.

\section{References}

1. Roberts C, Katzberg RW, Tallents R, Espeland MA, Handelman SL. The clinical predictability of internal derangements of temporomandibular joint. Oral Surg Oral Med Oral Pathol 1991; 71: 412-4.

2. Wilkes $\mathrm{CH}$. Internal derangements of the temporomandibular joint. Pathologicalvariations. Arch Otolaryngol Head Neck Surg 1989; 115: 469-77.

3. Buckley MJ, Merrill RG, Braun TW. Surgical management of internal derangement of the temporomandibular joint. J Oral Maxillofac Surg 1993; 51(Suppl 1): 20-7.

4. Kaplan AS, Assael LA. Temporomandibular disorders diagnosis and treatment. WB Saunders 1991; 95-103.

5. McNeill C, editor. Temporomandibulardisorders: guidelines for classification, assessment and management. 2nd ed. Chicago (IL): Quintessence Publishing Co.; 1993.

6. Palconet G, Ludlow JB, Tyndall DA, Lim PF. Correlating cone beam CT results with temporomandibular joint pain of osteoarthritic origin. Dentomaxillofac Radiol 2012; 41: 126-30.

7. Larheim TA, Westesson P, Sano T. Temporomandibular joint disk displacement: comparison in asymptomatic volunteers and patients. Radiology 2001; 218: 428-32.

8. Holmlund AB, Gynther GW, Axelsson S. Diskectomy in treatment of internal derangement of the temporomandibular joint. Follow-up at 1, 3 and 5 years. J Oral Maxillofac Surg 1993; 76: 972-1071.

9. Eriksson L, Westesson PL. Discectomy as an effective treatment for painful temporomandibular joint internal derangement: a 5-year clinical and radiographic follow-up. J Oral Maxillofac Surg 2001; 59: 750-9.

10. Farrar WB. Diagnosis and treatment of anterior dislocation of articular disc. N Y J Dent 1971; 41: 348-51.

11. Ericksson L, Westesson PL. Long-term evaluation of meniscectomy of the temporomandibular joint. J Oral Maxillofac Surg 1985; 43: 263-9.

12. Hall D. The role of discectomy for treating internal derangements of the temporomandibular joint. Oral Maxillofac Surg Clin North Am 1994; 6: 287.

13. Dolwick MF. The role of temporomandibular joint surgery in the treatment of patients with internal derangement. Oral Surg Oral Med Oral Pathol Oral Radiol Endod 1997; 83: 150-5.

14. Dworkin SF, LeResche L, DeRouen T, Von Korff M: Assessing clinical signs of temporomandibular disorders: reliability of clinical examiners. J Prosthet Dent 1990; 63: 574-9.

15. Miloro M, Henriksen B. Discectomy as the primary surgical option for internal derangement of the temporomandibular joint. J Oral Maxillofac Surg 2010; 68: 782-9.

16. Nyberg J, Adell R, Svensson B. Temporomandibular joint discectomy for treatment of unilateral internal derangements e a 5 year follow-up evaluation. Int J Oral Maxillofac Surg 2004; 33: 8-12.

17. Miloro M, McKnight M, Han MD, Markiewicz MR. Discectomy without replacement improves function in patients with internal derangement of the temporomandibular joint. J Craniomaxillofac Surg 2017; 45: 1425-31.

18. Dimitroulis $\mathrm{G}$. The use of dermis grafts after discectomy for internal derangement of the temporomandibular joint. J Oral Maxillofac Surg 2005; 63: 173-8. 
19. Holmund A, Lund B, Weiner CK. Discectomy without replacement for the treatment of painful reciprocal clicking or catching and chronic closed lock of the temporomandibular joint: a clinical follow-up audit. Br J Oral Maxillofac Surg 2013; 51: e211-4. doi: 10.1016/j.bjoms.2012.12.006 [Epub 2013 Jan 29].

20. Zhang SY, Liu XM, Yang C, Cai XY, Chen MJ, Haddad MS, et al. New arthroscopic disc repositioning and suturing technique for treating internal derangement of the temporomandibular joint: Part II-Magnetic resonance imaging evaluation. J Oral Maxillofac Surg 2010; 68: 1813-7. doi: 10.1016/j.joms.2009.08.012 [Epub 2009 Dec 30].

21. Dimitroulis G, McCullough M, Morrison W. Quality-of-life survey comparing patients before and after discectomy of the temporomandibular joint. J Oral Maxillofac Surg 2010; 68: 101-6.

22. Dimitroulis $\mathrm{G}$. Macroscopic and histologic analysis of abdominal dermis-fat grafts retrieved from human temporomandibular joints. J Oral Maxillofac Surg 2011; 69: 2329-33.
23. Mercuri LG, Ali FA, Woolson R. Outcomes of total alloplastic replacement with periarticular autogenous fat grafting for management of reankylosis of the temporomandibular joint. J Oral Maxillofac Surg 2008; 66: 1794-803.

24. Hansson LG, Eriksson L, Westesson PL. Magnetic resonance evaluation after temporomandibular joint diskectomy. Oral Surg Oral Med Oral Pathol Oral Radiol Endod 1992; 74: 801-10.

25. Takaku S, Sano T, Yoshida M. Longterm magnetic resonance imaging after temporomandibular joint discectomy without replacement. J Oral Maxillofac Surg 2000; 58: 739-45.

26. Goss AN. Toward an international consensus on temporomandibular joint surgery. Report of the Second International Consensus Meeting, April 1992, Buenos Aires, Argentina. Int J Oral Maxillofac Surg 1993; 22: 78-81. 